\title{
MYOCARDIAL INFARCTION AND STROKE: 16-YEAR RISK AND STRESS AT WORK IN OPEN POPULATION OF 25-64-YEAR-OLD WOMEN IN RUSSIA/SIBERIA (WHO MONICA-PSYCHOSOCIAL PROGRAM)
}

\author{
Gafarov Valery, Panov Dmitry, Gromova Elena, Gagulin Igor, Gafarova Almira
}

Aim. To determine the effects of stress at workplace on the risks (HR: hazard ratio) of development of myocardial infarction and stroke in open population of 25-64-yearold women in Russia/Siberia (Novosibirsk)

Material and methods. Random representative sample of 25-64-year-old women $(n=870)$ was examined in a framework of WHO MONICA-Psychosocial program in one of Novosibirsk districts. Stress at workplace was studied by using the Karasek scale; attitudes to work and prophylactic exams were studied by using the scale of "Knowledge and attitude towards one's own health" of WHO MONICA-Psychosocial program. During 16 years (1994-2010), all first-time cases of myocardial infarction and stroke were studied in the cohort based on the WHO program of Register of Acute Myocardial Infarction and all available documentation. Cox regression model was used for determination of myocardial infarction and stroke risk over 16 years of follow-up.

Results. Prevalence rate of high level of stress in open population of 25-64-yearold women was $31,6 \%$. High levels of stress at work were associated with high levels of responsibility, inability to get rest at the end of workday, frequent professional dissatisfaction, and decreased working ability. For 16 years, HR was by 3,22 times higher for myocardial infarction $(p<0,05)$ and 1,96 times higher for stroke $(p<0,05)$ in women with stress at work. Rates of myocardial infarction and stroke were higher in married women who experienced stress at work, belonged to categories of managers and physical labor, and had high and low level of education.

Conclusion. Prevalence of high level of stress at workplace is significant in open population of 25-64-year-old women in Russia/Siberia (Novosibirsk). In the presence of stress at workplace, HR of myocardial infarction and stroke were 2 to 3 times higher than without it. Social gradient affected HR of infarct and stroke.

Russ J Cardiol 2016, 4 (132), Engl.: 135-139

http://dx.doi.org/10.15829/1560-4071-2016-4-eng-135-139

Key words: cardiology, myocardial infarction, stroke, stress at workplace, hazard ratio, social gradient.

Institute of internal and preventive medicine, Novosibirsk, Russia

Corresponding author. Gafarov Valery, Senior research of Laboratory of Psychological and Sociological Issues, Collaborative Laboratory of Cardiovascular Diseases Epidemiology, Novosibirsk, valery.gafarov@gmail.com

$\mathrm{Cl}$ - confidence interval, CVD - cardiovascular diseases, IHD - ischemic heart disease, $\mathrm{HR}$ - hazard ratio, $\mathrm{Ml}$ - myocardial infarction.

Received February 17, 2016.

Revision received February 18, 2016.

Accepted February 25, 2016.

\section{ИНФАРКТ МИОКАРДА И ИНСУЛЬТ: 16-ЛЕТНИЙ РИСК И СТРЕСС НА РАБОТЕ В ОТКРЫТОЙ ПОПУЛЯЦИИ СРЕДИ ЖЕНЩИН 25-64 ЛЕТ В РОССИИ/СИБИРИ (ПРОГРАММА ВОЗ "МОНИКА- ПСИХОСОЦИАЛЬНАЯ"}

\author{
Gafarov Valery, Panov Dmitry, Gromova Elena, Gagulin Igor, Gafarova Almira
}

Цель. Для определения влияния стресса на рабочем месте на риск развития (Hazard ratio - HR) инфаркта миокарда и инсульта в открытой популяции среди женщин 25-64 лет в России/Сибири (г.Новосибирск).

Материал и методы. Случайная репрезентативная выборка женщин 25-64 лет (N=870) была обследована в рамках программы ВОЗ "МОНИКА-психосоциальная" в одном из районов г.Новосибирска. Стресс на рабочем месте был изучен с использованием шкалы Karasek; отношение к труду и профилактическим осмотрам исследованы с помощью шкалы "Знание и отношение к собственному здоровью" программы ВОЗ “МОНИКА-психосоциальная”. В течение 16 лет (1994-2010), все первичные случаи инфаркта миокарда и инсульта изучали в когорте на основе программы ВОЗ "Регистр острого инфаркта миокарда" и всей имеющейся медицинской документации. Кокс-регрессионная модель была использована для определения риска инфаркта миокарда и инсульта в течение 16 лет наблюдения.

Результаты. Распространенность высокого уровня стресса на работе в открытой популяции среди женщин в возрасте 25-64 лет составила 31,6\%. Высокий уровень стресса на работе был связан с высоким уровнем ответственности, невозможностью отдохнуть в конце рабочего дня, частой профессиональной неудовлетворенностью и снижением трудоспособности. В тече-

Stress associated with work is one of the most important problems of healthcare and safety in developing countries. Changes in the world tendencies imply an increase in requirements for all areas of activity: mass layoffs, outsourcing, high demands for flexibility and necessary skills, and disregard to workplace safety measures, excess work- ние 16 лет, HR был на 3,22 раза выше, для инфаркта миокарда ( $p<0,05)$ и 1,96 раза выше для инсульта $(p<0,05)$ у женщин со стрессом на работе. Частота инфаркта миокарда и инсульта была выше у замужних женщин, которые испытывали стресс на работе, и относились к категории руководителей или физического труда, с высоким и низким уровнем образования.

Заключение. Распространенность высокого уровня стресса на рабочем месте является существенным в открытой популяции среди женщин в возрасте 25-64 лет в России/Сибири (Новосибирск). При наличии стрессовых ситуаций на рабочем месте, HR инфаркта миокарда и инсульта были в 2-3 раза выше, чем без них. Социальный градиент влияет на HR инфаркта и инсульта.

Российский кардиологический журнал 2016, 4 (132), Англ.: 135-139 http://dx.doi.org/10.15829/1560-4071-2016-4-eng-135-139

Ключевые слова: кардиология, инфаркт миокарда, инсульт, стресс на рабочем месте, отношение рисков, социальный градиент.

НИИ терапии и профилактической медицины, Новосибирск, Россия.

load, psychological pressure, and work-leisure imbalance. All these factors contribute to stress associated with work. Possible relation of stress at work with loss of workforce potential (sick leaves) [1,2] shows significant negative effect of distress on the economic indicators. At the same time, lack of prospective studies that involve evaluation of 
individual characteristics of workers affects understanding of the causal relationships between stress and genesis of somatic disorders especially of cardiovascular diseases (CVD) [3]. The model of stress, focused on the aspects of organization of workplace and work environment [2], identifies the groups subjected to stress at work and stratified by age, gender, professional class, and education level. In perspective, this model contributes to the development of theoretically-based methods of prophylactics at workplace.

In this regard, the aim of the present study was to determine the prevalence rates of stress at work in an open population of 25-64-year-old women and to investigate the effects of stress on hazard ratios (HR) for myocardial infarction and stroke during the long-term period of observation (16 years).

\section{Material and methods}

In a framework of the third screening of the WHO MONICA program and MONICA-Psychological subprogram (MOPSY) in 1994 [4], we studied a random representative sample of women $(n=870)$ aged 25-64 years, residents of one of the Novosibirsk districts (Table 1). The sample was formed based on the electoral lists by using the random numbers table. The response rate was $72,5 \%$. The examination was conducted according to the protocol of the MONICA program.

Program of the psychosocial screening study consisted in the registration of social and demographic data including marital status, education level, and psychosocial tests. The levels of stress at workplace were studied by using Karasek scale [5]; attitudes to work and to prophylactic health exams were elucidated by using a scale of "knowledge and attitude towards one's own health" of the WHO MONICA-Psychosocial program.

After the exclusion of all individuals with cardiovascular pathology (arterial hypertension, ischemic heart disease (IHD), stroke, and diabetes mellitus) at the moment of the screening, the cohort was formed $(\mathrm{n}=560)$. During the control period (from 1994 to 2010), 35 cases $(6,3 \%)$ of first-time stroke were found in the cohort based on medical examinations, medical documentation analysis, and death certificates. According to the WHO program "Register of Acute Myocardial Infarction” [6], 15 cases (2,7\%)

\section{Table 1}

\section{Age-dependent distribution of 25-64-year-old women examined in the screening study according to the WHO MONICA program (1994)}

\begin{tabular}{|l|l|l|}
\hline Age groups & N & $\%$ \\
\hline $25-34$ & 214 & 24,6 \\
\hline $35-44$ & 192 & 22,1 \\
\hline $45-54$ & 231 & 26,6 \\
\hline $55-64$ & 233 & 26,8 \\
\hline $25-64$ & 870 & 100,0 \\
\hline
\end{tabular}

of first-time myocardial infarction (MI) were identified. Statistical analysis was performed by using SPSS 11.5 software package. Cox regression model was used to evaluate Hazard ratio (HR) or MI and stroke in the study cohort. To test statistical significance of differences between groups, chi-square test $\left(\chi^{2}\right)$ was used. Values were considered statistically significant when $\mathbf{P}$ was $<0,05$.

\section{Results}

In an open population of 25-64-year-old women, the prevalence rates for high and moderate levels of stress at work were $31,6 \%$ and $50,7 \%$, respectively. Proportions of women with high levels of stress at work did not significantly differ between the age groups.

The study of women's attitudes to work showed that $40 \%$ of them changed their specialty during the last year and $28 \%$ of respondents began to perform extra work. Almost $42 \%$ of women were not pleased with their work. Among them, 1,7\% disliked their work, 5,3\% did not like it, and $34,8 \%$ moderately liked their work. Almost half of women $(46,5 \%)$ had work with high or very high responsibility. Moreover, $42,2 \%$ of respondents reported about the changes in work responsibility during the last 12 months. About $40 \%$ of women responded that they could not relax or get rest after workday. Women of the older age groups tended to change their specialty less often (Table 2). Respondents from the younger age groups more often performed extra work. Older women reported about a decrease in the workload $\left(34,1 \%\right.$ vs. $11,8 \% ; \chi^{2}=46,43 ; \mathrm{df}=6$; $\mathrm{p}<0,001)$. Workplace responsibility decreased or did not change in the older age groups for the last year; younger age groups reported about an increase in responsibility at workplace. Ability to have rest at home was reported less often in the younger age groups compared with the respondents of the older age groups $(12,1 \%$ vs. $26,9 \%$; $\left.\chi^{2}=45,5 ; \mathrm{df}=12 ; \mathrm{p}<0,001\right)$. Aging was associated with an increase in the proportion of persons who reported about a decrease in their working efficiency.

Attitude to own work and prophylactic health exams is an important indicator. Majority of women (64\%) reported that they would continue working if they felt unwell at workplace. Only $38 \%$ of women said they would stay at home in case of feeling unwell and do their best to return to work.

The age-dependent results on attitudes to work and prophylactic health exams in women are presented in Table 3. In the older age groups, we documented an increase in responsibility of women for their own health. For instance, the number of women who would seek medical assistance in case of worsening of their health increased almost three-fold whereas individuals from the younger age groups (25-34 and 35-44 years) reported more often that they would prefer to continue their work despite feeling unwell, however they would make more efforts for the quickest recovery and return to work compared with the older age group ( $11 \%$ vs. $34 \% ; 73,6 \%$ vs. $43 \% ; \chi^{2}=55,15$; 
Table 2

Attitudes to work in an open population of 25-64-year-old women depending on age

\begin{tabular}{|c|c|c|c|c|c|c|c|c|}
\hline \multirow[t]{3}{*}{ Question/attitude } & \multicolumn{8}{|c|}{ Age groups } \\
\hline & \multicolumn{2}{|c|}{$25-34$} & \multicolumn{2}{|c|}{$35-44$} & \multicolumn{2}{|c|}{$45-54$} & \multicolumn{2}{|c|}{$55-64$} \\
\hline & $\mathrm{N}$ & $\%$ & $\mathrm{~N}$ & $\%$ & $\mathrm{~N}$ & $\%$ & $\mathrm{~N}$ & $\%$ \\
\hline $\begin{array}{l}\text { 14. Have your specialty change during the last } 12 \text { years? } \\
\text { 1. Yes } \\
\text { 2. No } \\
\chi^{2}=15,49 \mathrm{df}=3 p<0,01\end{array}$ & $\begin{array}{l}79 \\
103\end{array}$ & $\begin{array}{l}43,4 \\
56,6\end{array}$ & $\begin{array}{l}97 \\
111\end{array}$ & $\begin{array}{l}46,6 \\
53,4\end{array}$ & $\begin{array}{l}56 \\
125\end{array}$ & $\begin{array}{l}30,9 \\
69,1\end{array}$ & $\begin{array}{l}40 \\
91\end{array}$ & $\begin{array}{l}30,5 \\
69,5\end{array}$ \\
\hline $\begin{array}{l}\text { 16. Are you pleased with your work? } \\
\text { 1. I do not like it at all } \\
\text { 2. I do not like it } \\
\text { 3. Moderately } \\
\text { 4. O like it } \\
\text { 5. I like it very much } \\
\chi^{2}=20,47 \mathrm{df}=12 p=0,059\end{array}$ & $\begin{array}{l}4 \\
15 \\
72 \\
81 \\
10\end{array}$ & $\begin{array}{l}2,2 \\
8,2 \\
39,6 \\
44,5 \\
5,5\end{array}$ & $\begin{array}{l}3 \\
7 \\
76 \\
115 \\
6\end{array}$ & $\begin{array}{l}1,4 \\
3,4 \\
36,7 \\
55,6 \\
2,9\end{array}$ & $\begin{array}{l}3 \\
7 \\
59 \\
98 \\
13\end{array}$ & $\begin{array}{l}1,7 \\
3,9 \\
32,8 \\
54,4 \\
7,2\end{array}$ & $\begin{array}{l}2 \\
8 \\
33 \\
68 \\
13\end{array}$ & $\begin{array}{l}1,6 \\
6,5 \\
26,6 \\
54,8 \\
10,5\end{array}$ \\
\hline $\begin{array}{l}\text { 17. Have your responsibility at work change during the last } 12 \text { months? } \\
\text { 1. It did not change } \\
\text { 2. It increased } \\
\text { 3. It decreased } \\
\chi^{2}=40,00 \mathrm{df}=6 \mathrm{p}<0,001\end{array}$ & $\begin{array}{l}105 \\
70 \\
6\end{array}$ & $\begin{array}{l}58,0 \\
38,7 \\
3,3\end{array}$ & $\begin{array}{l}104 \\
90 \\
11\end{array}$ & $\begin{array}{l}50,7 \\
43,9 \\
5,4\end{array}$ & $\begin{array}{l}105 \\
63 \\
13\end{array}$ & $\begin{array}{l}58,0 \\
34,8 \\
7,2\end{array}$ & $\begin{array}{l}83 \\
20 \\
20\end{array}$ & $\begin{array}{l}67,5 \\
16,3 \\
16,3\end{array}$ \\
\hline $\begin{array}{l}\text { 18. How do you estimate responsibility of your work during the last } 12 \text { months? } \\
\text { 1. Insignificant } \\
\text { 2. Moderate } \\
\text { 3. High } \\
\text { 4. Very high } \\
\chi^{2}=46,11 \mathrm{df}=9 \mathrm{p}<0,001\end{array}$ & $\begin{array}{l}10 \\
93 \\
66 \\
9\end{array}$ & $\begin{array}{l}5,6 \\
52,2 \\
37,1 \\
5,1\end{array}$ & $\begin{array}{l}17 \\
86 \\
88 \\
12\end{array}$ & $\begin{array}{l}8,4 \\
42,4 \\
43,3 \\
5,9\end{array}$ & $\begin{array}{l}14 \\
66 \\
91 \\
9\end{array}$ & $\begin{array}{l}7,8 \\
36,7 \\
50,6 \\
5,0\end{array}$ & $\begin{array}{l}31 \\
47 \\
38 \\
5\end{array}$ & $\begin{array}{l}25,6 \\
38,8 \\
31,4 \\
4,1\end{array}$ \\
\hline $\begin{array}{l}\text { 20. Have you been able to relax and rest after regular workday during the last } 12 \text { months? } \\
\text { 1. No, never } \\
\text { 2. Rarely } \\
\text { 3. It depends } \\
\text { 4. Often } \\
\text { 5.Yes, always } \\
\chi^{2}=45,5 d f=12 p<0,001\end{array}$ & $\begin{array}{l}12 \\
69 \\
78 \\
16 \\
6\end{array}$ & $\begin{array}{l}6,6 \\
38,1 \\
43,1 \\
8,8 \\
3,3\end{array}$ & $\begin{array}{l}9 \\
76 \\
92 \\
26 \\
5\end{array}$ & $\begin{array}{l}4,3 \\
36,5 \\
44,2 \\
12,5 \\
2,4\end{array}$ & $\begin{array}{l}11 \\
46 \\
90 \\
17 \\
17\end{array}$ & $\begin{array}{l}6,1 \\
25,4 \\
49,7 \\
9,4 \\
9,4\end{array}$ & $\begin{array}{l}9 \\
29 \\
49 \\
10 \\
22\end{array}$ & $\begin{array}{l}7,6 \\
24,4 \\
41,2 \\
8,4 \\
18,5\end{array}$ \\
\hline
\end{tabular}

Table 3

\section{Attitudes to work and prophylactic health exams in an open population of 25-64-year-old women depending on age}

\begin{tabular}{|c|c|c|c|c|c|c|c|c|}
\hline \multirow[t]{3}{*}{ Question/attitude } & \multicolumn{8}{|c|}{ Age groups } \\
\hline & \multicolumn{2}{|c|}{$25-34$} & \multicolumn{2}{|c|}{$35-44$} & \multicolumn{2}{|c|}{$45-54$} & \multicolumn{2}{|c|}{$55-64$} \\
\hline & $\mathrm{N}$ & $\%$ & $\mathrm{~N}$ & $\%$ & $\mathrm{~N}$ & $\%$ & $\mathrm{~N}$ & $\%$ \\
\hline $\begin{array}{l}\text { 11. What do you do if you feel unwell at work? (retired and unemployed } \\
\text { respond as they were employed) } \\
\text { 1. I continue work } \\
\text { 2. I limit work and rest } \\
\text { 3. I go to see a doctor } \\
\chi^{2}=55,15 \mathrm{df}=6 \mathrm{p}<0,001\end{array}$ & $\begin{array}{l}134 \\
27 \\
21\end{array}$ & $\begin{array}{l}73,6^{\text {** }} \\
14,8 \\
11,5\end{array}$ & $\begin{array}{l}134 \\
54 \\
20\end{array}$ & $\begin{array}{l}64,4 \\
26,0 \\
9,6\end{array}$ & $\begin{array}{l}124 \\
34 \\
25\end{array}$ & $\begin{array}{l}67,8 \\
18,6 \\
13,7\end{array}$ & $\begin{array}{l}58 \\
31 \\
46\end{array}$ & $\begin{array}{l}43,0 \\
23,0 \\
34,1^{\text {** }}\end{array}$ \\
\hline $\begin{array}{l}\text { 12. What do you undertake if you have cold and fever? } \\
\text { 1. I work as usual } \\
\text { 2. I stay at home and do my best to return to work as soon as possible } \\
\text { 3. I remain at home until I feel better } \\
\chi^{2}=11,31 \mathrm{df}=6 \mathrm{p}=0,079\end{array}$ & $\begin{array}{l}80 \\
70 \\
32\end{array}$ & $\begin{array}{l}44,0 \\
38,5 \\
17,6\end{array}$ & $\begin{array}{l}99 \\
88 \\
23\end{array}$ & $\begin{array}{l}47,1 \\
41,9 \\
11,0\end{array}$ & $\begin{array}{l}97 \\
63 \\
18\end{array}$ & $\begin{array}{l}54,5 \\
35,4 \\
10,1\end{array}$ & $\begin{array}{l}61 \\
45 \\
25\end{array}$ & $\begin{array}{l}46,6 \\
34,4 \\
19,1\end{array}$ \\
\hline $\begin{array}{l}\text { 13. How do you think? - Is prophylactic health exam useful? } \\
\text { 1. Yes, it is useful } \\
\text { 2. Maybe, yes } \\
\text { 3. Maybe, no } \\
\text { 4. It is useless }\end{array}$ & $\begin{array}{l}137 \\
44 \\
1 \\
1\end{array}$ & $\begin{array}{l}74,9 \\
24,0 \\
0,5 \\
0,5\end{array}$ & $\begin{array}{l}157 \\
52 \\
0 \\
0\end{array}$ & $\begin{array}{l}75,1 \\
24,9 \\
0 \\
0\end{array}$ & $\begin{array}{l}135 \\
49 \\
0 \\
0\end{array}$ & $\begin{array}{l}73,4 \\
26,6 \\
0 \\
0\end{array}$ & $\begin{array}{l}108 \\
27 \\
1 \\
0\end{array}$ & $\begin{array}{l}79,4 \\
19,9 \\
0,7 \\
0\end{array}$ \\
\hline
\end{tabular}




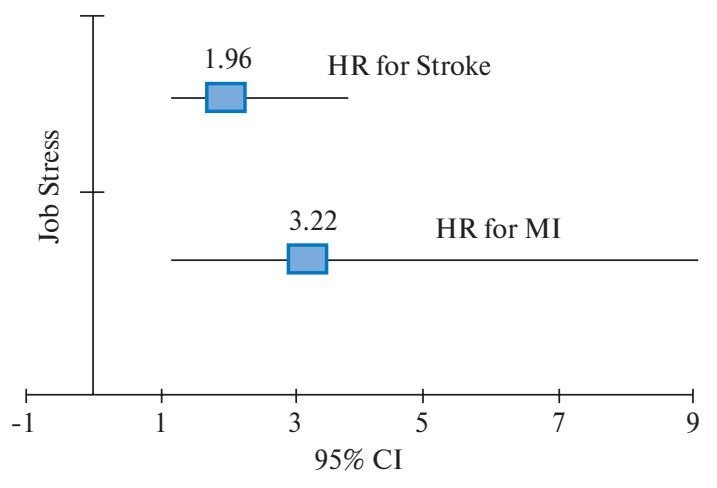

Figure 1. Risk of stroke and myocardial infarction among 25-64-year-old women with high levels of stress at workplace in an open population during 16 years.

$\mathrm{df}=6 ; \mathrm{p}<0,001)$. The rates of positive attitude to prophylactic health exams were nearly $100 \%$ in all age groups.

We studied the relationships between workplace stress and social characteristics of women who developed MI and stroke.

Pattern of marital status in the cohort of women with stroke who experienced stress at work was as follows: never married $(4,5 \%)$, married $(72,7 \%)$, divorced $(18,2 \%)$, and widowed $(4,5 \%)$. Pattern of marital status in the cohort of women with MI who experienced stress at work was as follows: married $(66,7 \%)$, divorced $(22,2 \%)$, and widowed $(11,1 \%)$. Increasing trends in the rates of stroke and MI were documented in married women with stress in the family compared with single, divorced, and widowed women.

Education levels in cohort of women with stroke and stress at work were as follows: university education $(13,6 \%)$; incomplete higher education/secondary specialized college $(31,8 \%)$; high school diploma $(27,3 \%)$; and elementary education $(27,3 \%)$. Women with high school diploma and elementary education who had workplace stress showed higher rate of stroke compared with women who had higher education. Pattern of education in individuals with MI and stress at work revealed prevalence of completely opposite categories: higher education $(37,5 \%)$, elementary education $(37,5 \%)$, and secondary education $(25 \%)$.

Professional status in the groups of women with workplace stress and stroke showed the following structure: middle managers $(9,1 \%)$; managers $(4,5 \%)$; technical and engineering employees $(18,2 \%)$; physically demanding jobs $(4,5 \%)$; moderately physically demanding jobs $(22,7 \%)$; easy manual labor $(18.2 \%)$; and retired $(22,7 \%)$. Professional status in women with stress and MI was as follows: managers (12,5\%); technical and engineering employees $(37,5 \%)$; easy manual labor $(12,5 \%)$; and retired $(37,5 \%)$. Concerning the professional characteristics, data showed tendency toward an increase in the frequency of stroke among women of easy manual labor who had workplace stress; the proportion of women with MI was higher among the stressed pensioners and technical/engineering employees.

For 16 years (1994-2010), women with the high level of stress at workplace had 1,96-fold HR for stroke com- pared with individuals with the lower levels of stress (95.0\% CI 1,01-3,79; $\mathrm{p}<0,05)$. In women with the high level of stress at workplace, HR for MI was 3,22 times higher $(95.0 \%$ CI 1,15-9,04; p<0,05) (Figure 1).

\section{Discussion}

Every third woman, residing in West Siberian metropolis, experiences stress at workplace. According to data of the fourth study of the European Working Conditions Survey conducted in the European Union countries in 2005, 20,3\% of women report about the presence of stress at workplace and $31 \%$ of women believe that work affects their health [7]. The highest levels of stress at workplace were found in the developing countries of East Europe; the lowest levels were found in Great Britain and the Netherlands [7, 8].

High proportion of women (over $40 \%$ ) reports about an increase in work responsibility and load as well as inability to have rest after work predominantly in younger age groups. In the European countries, individuals who belong to the most active age groups of 25-39 years (23\%) and 40-54 years $(24 \%)$ present with complains of stress; frequency of the reports about fatigue (exhaustion) and stress decreases in the older age categories [9]. In combination with inability to have rest at home after work, these observations explain the higher rates of cardiovascular events in married women experiencing workplace stress which was shown in the present study: about $70 \%$ of women with MI/ stroke and stress at work were in the category of "married". Modern views support the idea that, apart from the demand for the balance between efforts and rewards at work, the balance between family and work (career) should be improved especially in workers who have small children [10]. Despite the fact that family-career conflict is relevant for both genders, the disbalance is more pronounced in women [11-13].

Obtained data showed that $42 \%$ of women were not pleased with their work. In our opinion, this observation is explained by both environmental (such as position held etc.) and personal traits $[14,15]$. Women who are unsatisfied with the existing situation at work often report about the inefficacious organization at workplace, poorly defined work tasks, lack of tools to solve professional tasks, and the presence of unresolved conflicts [16].

Almost half of woman in our study estimated their responsibility at work as high. High frequency of terminations of employment and layoffs during that period explains an increase of work load in the rest of personnel, erases the boundaries between the professional categories, and often exposes women to the submissive position both in budgetary and private sectors of economics [17]. As a result, women have fewer supervisory functions and the levels of tension and stress at workplace increase [18, 19]. Such changes hinder the protective effects of education on cardiovascular health in women; frequency of the cardiovascular events becomes independent from the education level in the presence of high level of stress at work. Accord- 
ing to our data, the proportion of individuals with MI was similar both for women with higher and elementary education though the rate for stroke showed an upward tendency in the presence of the lower education level.

The large proportion of women (64\%) reported that they would prefer to continue work if they felt unwell at workplace. Health-related complains at workplace are often associated with the high levels of stress in women at place of production [1]. At the same time, insufficient care for own health and poor awareness in the presence of hard work are associated with the adverse lifestyle and cardiovascular risk factors [20-23] and can be one of the pathogenetic mechanisms of health deterioration and CVD development. The obtained results showed tendency to increase in the stroke rates among women in the category of "physical labor" emphasizing high level of cardiovascular risk in this class [24].

Therefore, our study demonstrated that stress associated with work significantly increased HR for stroke and MI among women in an open population. Relationships between the professional characteristics and IHD were demonstrated based on other large studies such as British Whitehall II Study and Finnish Helsinki Health Study [25], but only Framingham Offspring Study showed that workplace stress increased risk of IHD in women [26]. The

\section{References}

1. Holmgren K, Dahlin-Ivanoff S, Björkelund C, Hensing G. The prevalence of work-related stress, and its association with self-perceived health and sick-leave, in a population of employed Swedish women. BMC Public Health. 2009; 9: 73.

2. Karasek R, Theorell T. Healthy work: stress, productivity and the reconstruction of working life. New York: Basic Books, 1990.

3. Boedeker W, Klindworth H. Hearts and minds at work in Europe. A European work-related public health report on cardiovascular diseases and mental ill health. BKK Bundesverband: Federal Association of Company Health Insurance Funds, Essen, 2007.

4. MONICA Psychosocial Optional Study. Suggested measurement instruments. Copenhagen: WHO Facsimile Urgent 3037 MRC, 1988; p. 33.

5. Karasek R.A. Job demands, job decision latitude and mental strain: implications for job redesign. Admin Sci Q 1979; 24: 285-307.

6. Gafarov V.V. Epidemiology and prevention of cardiovascular diseases in large industrial center of West Siberia. Novosibirsk: Polygraphist, 1992.

7. Milczarek M., Schneider E., González E. Report to European Agency for Safety and Health at Work: OSH in figures: stress at work - facts and figures. Luxembourg: Office for Official Publications of the European Communities, 2009.

8. Daniels K. Perceived risk from occupational stress: a survey of 15 European countries. Occupational and Environmental Medicine 2004; 61: 467-70.

9. European Foundation for the Improvement of Living and Working Conditions, Fourth European Working Conditions Survey. Luxembourg: Office for Official Publications of the European Communities, 2006.

10. Franche R. L., Williams A., Ibrahim S., et al. Path analysis of work conditions and work-family spillover as modifiable workplace factors associated with depressive symptomatology. Stress and Health 2006; 22: 91-103.

11. Jansen N.W., Kant I.J., van Amelsvoort L. G., et al. Work-family conflict as a risk factor for sickness absence. Occup Environ Med 2006; 63(7): 488-94.

12. Gafarov V.V., Panov D.O., Gromova E.A., et al. The influence of depression on risk development of acute cardiovascular diseases in the female population aged 25-64 in Russia. Int J Circumpolar Health 2013; 72: 1-5.

13. Gafarov V.V., Panov D. O., Gromova E. A., et al. Risk of arterial hypertension and trait anxiety in open population of 25-64-year-old women (16-year epidemiological study - WHO MONICA-Psychosocial program). Journal of Arterial Hypertension 2012; 18(4): 298-302.

14. Phillips S., Sen D., McNamee R. Prevalence and causes of self-reported work-related stress in head teachers. Occup Med (Lond) 2007; 57(5): 367-6.

15. Heslop P., Smith G. D., Metcalfe C, et al. Change in job satisfaction, and its association with self-reported stress, cardiovascular risk factors and mortality. Soc Sci Med 2002; 54(10): 1589-99. other long-term prospective study showed that the high level of psycho-emotional stress in individuals who lost their job significantly increased risk for stroke and MI [27]. Some investigators have been denying the gender-related effects of professional stress on CVD risk [28], but this merely denotes the need for further studies of gender aspects of psychosocial characteristics at work.

\section{Conclusion}

1. Prevalence of pronounced level of stress at workplace in an open population of 25-64-year-old women in Russia/Siberia was high $(31,6 \%)$.

2. In an open population of 25-64-year-old women, the high levels of stress were associated with the high responsibility at work, inability to have rest at the end of workday, frequent professional dissatisfaction, and decrease in working efficiency.

3. Social gradient ("married" marital status; professional categories of managers and physical labor workers; high and low education levels) affected HR for MI and stroke.

4. In an open population of 25-64-year-old women with high levels of stress associated with work, HRs for MI and stroke were 3,22-fold and 1,96-fold higher over 16 years, respectively.

16. Holmgren K., Dahlin Ivanoff S. Women on sickness absence - views of possibilities and obstacles for returning to work. A focus group study. Disabil Rehabil 2004; 26(4): 213-22.

17. Statistics Sweden: Women and men in Sweden 2006. Stockholm: Official Statistics of Sweden, 2006.

18. Lidwall U., Marklund S. What is healthy work for women and men? A case-control study of gender- and sector-specific effects of psycho-social working conditions on long-term sickness absence. Work 2006; 27(2): 153-63.

19. Gjerdingen D., McGovern P., Bekker M., et al. Women's work roles and their impact on health, well-being, and career: comparisons between the United States, Sweden, and The Netherlands. Women Health 2000; 31(4): 1-20.

20. Gafarov V.V., Pak V. A., Gagulin I. V. et al. The WHO MONICA-based study of awareness and attitude to own health in 25-64-year-old women in Novosibirsk. Siberian Medical Journal (Tomsk) 2010; 25(4): 131-7.

21. Gafarov V.V., Gagulin I.V., Gafarova A.V., et al. Smoking and stress in the family and workplace: epidemiological study. The World of Science, Culture and Education 2013; 1(38): 250-2.

22. Kivimäki M., Leino-Arjas P., Luukkonen R. Work stress and risk of cardiovascular mortality: prospective cohort study of industrial employees. BMJ 2002; 325(7369): 857.

23. Michie S., Williams S. Reducing work-related psychological ill health and sickness absence: a systematic literature review. Occup Environ Med 2003; 60(1): 3-9.

24. Myint P. K, Luben R. N., Welch A. A. Effect of age on the relationship of occupational social class with prevalence of modifiable cardiovascular risk factors and cardiovascular diseases. A population-based cross-sectional study from European Prospective Investigation into Cancer - Norfolk (EPIC-Norfolk). Gerontology 2006: 52(1): 51-58

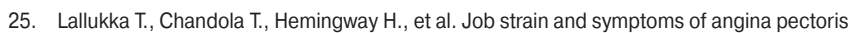
among British and Finnish middle-aged employees. J Epidemiol Community Health 2009; 63(12): 980-5.

26. Eaker E. D., Sullivan L. M., Kelly-Hayes M. Does job strain increase the risk for coronary heart disease or death in men and women? The Framingham Offspring Study. Am J Epidemiol 2004; 160(10): 1031-2.

27. Gallo W. T., Teng H.M., Falba T. A., et al. The impact of late career job loss on myocardial infarction and stroke: a 10 year follow up using the health and retirement survey. Occup Environ Med 2006; 63(10): 683-7.

28. Siegrist J., Dragano N. Psychosocial stress and disease risks in occupational life Results of international studies on the demand-control and the effort-reward imbalance models. Bundesgesundheitsblatt Gesundheitsforschung Gesundheitsschutz 2008 ;51(3): 305-12. 